\title{
NEW TRENDS IN MIGRATORY AND REFUGEE LAW IN BRAZIL: THE EXPANDED REFUGEE DEFINITION
}

Catherine Tinker

\begin{abstract}
Doctor of Juridical Science (J.S.D.) and LL.M. New York University Law School; J.D. George Washington University. Seton Hall University School of Diplomacy and International Relations and Visiting Professor, UFRGS Faculdade do Direito. NYC Bar Association Chair of European Affairs Committee and organizer of series on Migration into Europe.

dr.catherinetinker@gmail.com
\end{abstract}

Laura Madrid Sartoretto

\begin{abstract}
Master of Laws Candidate at Faculdade de Direito da Universidade Federal do Rio Grande do Sul, LL.M University College London Faculty of Laws. Co-coordinator of Cátedra Sérgio Vieira de Mello UFRGS. Member of the RS Human Mobility Forum, Lawyer at the Advisory Group for Refugees and Migrants (GAIRE-UFRGS). laurams11@yahoo.com.br
\end{abstract}

\begin{abstract}
This paper aims to explore new trends in Brazilian refugee and migratory law in the last 20 years. In doing so it addresses the evolution of the definition of "refugee" in Brazil, expanding the eligibility grounds provided by the 1951 Geneva Convention on the Status of Refugees (1951 Convention). Reviewing international and regional refugee law, the article analyzes the broader understanding of the notion of "refuge" and its complexity expressed in regional and national legal frameworks, taking account of lawyers, scholars and activists who criticize the narrow scope of the classical refugee definition from 1951 which has become distant from current refugee voices and struggles. At the domestic level, although the 1980 Aliens Statute (Act. n. 6815/80) is still in effect, there have been important changes in refugee law in Brazil since the implementation of the 1997 Refugee Statute (Act n. 9.474/97), influenced by the 1984 Cartagena Declaration (a regional soft law instrument) regarding the definition of "refugee". Exploring the interconnection of the Refugee Statute and complementary forms of human rights protection which fall outside the scope of international refugee law, the article concludes that in the
\end{abstract}


specific case of Haitians in Brazil, the broader protections of Brazilian refugee law should be available rather than the complementary system of humanitarian visas.

\author{
Key-words: Refugee - Migration - Brazil - Complementary protection \\ - Human rights law
}

\title{
1. INTRODUCTION
}

We have seen in Latin America and especially in Brazil some of the most important developments in refugee law ${ }^{1}$ in the last several decades, especially regarding the definition of "refugee"

1 It is important to clarify that some terms have different meanings in Latin American compared to the US and the EU. The term "asylum" (asilo) as applied in international refugee law is not used in the same way within Latin America. Asilo is a different legal instrument, regulated by the 1889 Montevideo Treaty on International Criminal Law. Asylum was also mentioned in the 1982 Asylum Convention, signed in Havana; the 1933 Convention on Political Asylum; and the 1954 Convention on Diplomatic Asylum. The instrument had its apex during the dictatorships in the Southern Cone in order to protect individuals who were being persecuted because of their political opinions. It can be argued, therefore, that territorial asylum is currently a Latin American institution due to its frequent usage within the region.

Countries outside the continent do apply territorial asylum sporadically, but they do not recognize it as an international law norm equal to refugee law. DUBLAN (2004, p. 242) explains that "In the case of some countries of the Southern Cone, although the situation of many political dissidents fully corresponded to the definition of the american conventions [the 1889 Montevideo Treaty on International Criminal Law, the 1982 Asylum Convention, signed in Havana, the 1933 Convention on Political Asylum and the 1954 Convention on Diplomatic Asylum], this framework did not exist in the ability of governments to materially face a situation of massive persecution which were happening in other countries of the continent, or to organize the orderly expatriation of those affected by military dictatorships. It is, for example, the case of Chile, which traditionally granted political asylum (asilo) following the traditional american standards and was not part of the 1951 Convention, the government requested support to UNHCR in 1971 to properly care for a string of refugees from Bolivia."

In Brazil, "asylum" and "refuge" (asilo e refúgio) also have different meanings. The instrument named as "asylum" is known as territorial or diplomatic asylum and is provided in the domestic and the regional conventions cited above. Asylum will be granted even when the applicant in not in the territory of the requested State. The asylee in Brazil is subject to the 1980 Aliens Statute, not to the 1994 Refugee Statute; the reverse is true for refugees. Asylum constitutes the exercise of a sovereign act of the State, a political decision whose fulfillment is not subject to any international body. Refuge is a conventional institute negotiated and established at an international level by States, under the auspices of an international organization. Asylum is granted only for those who are persecuted because of their political opinion. Refugee status, on the other hand, is multifactorial, and it is granted for a person who has a well-founded fear of persecution on the basis of his/her race, nationality, religion, membership in a particular social group, or political opinion.

2 Even before Latin America, the Organization of African Unity implemented in 1969 the OAU Convention Governing the Specific Aspects of Refugee Problems that adopted in its article 1(2) 
The classical definition ${ }^{3}$, provided by the 1951 Convention, adopts five grounds for granting asylum ${ }^{4}$ to an individual who has a well founded fear of persecution on the basis of his/her race, nationality, religion, membership in a particular social group, or political opinion. These categories are seen today as limited, outdated and not effective in dealing with contemporary forced fluxes of people (CHIMNI, 1998, p. 7).

The principle of non-refoulement, cornerstone of refugee protection, prevents states from returning a refugee to the frontiers of territories where his life or freedom would be threatened on account of his race, religion, nationality, particular social group or political opinion (REFUGEE CONVENTION, 1951) . This $^{5}$ principle has acquired a jus cogens nature ${ }^{6}$ and a broader application since the implementation of the 1984 Convention Against Torture and Other Cruel, Inhuman or Degrading Treatment or Punishment, which provides that no "State Party shall expel, return ("refouler") or extradite a person to another State where there are substantial grounds for believing that he would be in danger of being subjected to torture" (CONVENTION AGAINST TORTURE, 1984). In this sense, a person persecuted for reasons not encompassed by the 1951 Convention still cannot be sent back to a place where he or she is at risk of facing torture by the jus cogens nature granted to non-refoulement ${ }^{7}$ in the 1984 Convention Against Torture. This principle is recognized and respected in Europe and elsewhere.

Conscious of the jus cogens nature of the principle of nonrefoulement, Latin America has negotiated and established its own regional legal instrument on refugee protection. The 1984 Cartagena

an enlarged refugee definition, providing that "The term "refugee" shall also apply to every person who, owing to external aggression, occupation, foreign domination or events seriously disturbing public order in either part or the whole of his country of origin or nationality, is compelled to leave his place of habitual residence in order to seek refuge in another place outside his country of origin or nationality"

3 In this paper the expression "classical definition" of refugees refers to the 1951 definition of "refugee", expressed in Art. 1 of the Convention.

4 For an explanation on the differentiation of refuge and asylum in Latin America see footnote 1. 5 For more on the 1951 Geneva Convention Related to the Status of Refugees see: http:/www. unhcr.org/3b66c2aa10.html. Accessed on 5 Sep. 2015.

6 As to torture, the non-refoulement principle is has acquired a jus cogens nature. As noted by Allain (2007, p. 535): "beyond the States party to the 1951 Convention, all States are bound to respect the obligation not to refoule individuals, either unilaterally or in cooperation with other States, bilaterally or multilaterally."

7 For more on the jus cogens nature of non-refoulement see: ALLAIN, Jean. The jus cogens nature of non-refoulement. p. 533-588; BYRNE, R. and SHACKNOVE, A., The Safe Third Country Notion in European Asylum Law, p. 187, and the Case of M.S.S. v. Belgium and Greece at the ECHR (Application no. 30696/09), 21 Jan 2011. pp. 71-5. 
Declaration on Refugees ${ }^{8}$ has expanded the refugee definition and granted protection to people who did not fall within the classical definition framework, but could not be refouled to countries where they would be at risk of facing torture. In order to address this problem some states have created complementary protection systems ${ }^{9}$ which are not regulated by international refugee law.

A number of Latin American countries have been influenced by the broader refugee definition expressed in the Cartagena Declaration and have either adopted it directly or enacted laws which adopt it in whole or in part. The expanded definition of refugee was adopted in part when Brazil implemented its own Refugee Statute in 1997. This law repeats the most important aspects of the 1951 Convention as well as part of the Cartagena Declaration's enlarged refugee definition. It creates the possibility for individuals to apply for refuge in situations of "serious and widespread violation of human rights" in their country of origin.

In spite of the fact that Brazil has adopted a more generous definition of refugee in its domestic law, the eligibility process still prioritizes the classical definition provided by the 1951 Convention for granting refugee status, justifying the concession on the well-founded fear of persecution for race, nationality, religion, political opinion or membership in a group. How the refugee definition is applied in recent practice is illustrated by the case of Haitians in Brazil. Since 2010, Brazil has received a continued influx of migrants, especially from Haiti, after the catastrophic earthquake that displaced thousands of people in that country. However, Haitians are not recognized as refugees in Brazil under the Refugee Statute.

Instead, the country established an ad hoc complementary protection system to address this emergency situation and protect Haitians who arrive in Brazil. The Brazilian system adopted a

8 Cartagena Declaration on Refugees, available at www.oas.org/dil/1984_Cartagena_ Declaration_on_Refugees.pdf, accessed 5 Sep. 2015.

9 Cançado Trindade sees International Refugee Law, Humanitarian Law and Human Rights Law as complementary branches of human protection; he argues that the compartmentalized approach adopted in the classical doctrine of International Law has been criticized currently and gradually replaced by a more holistic view. (CANÇADO TRINDADE, 2004, p. 1). The complementary protection system adopted in Europe and in Latin America is based in the assumption of complementarity among these three branches of human protection and utilizes legal instruments from International Humanitarian Law, such as the Geneva Conventions on the Law of War, and Human Rights Law, such as the Convention Against Torture, the International Covenant on Civil and Political Rights, the International Covenant on Economic, Social and Cultural Rights among others, in order to offer a more comprehensive protection to forced migrants not protected by International Refugee Law. 
"humanitarian visa" instrument ${ }^{10}$ that covers forced migrants ${ }^{11}$ who do not fulfill the requirements of the 1951 Convention definition of refugee. It was necessary to do this because the 1980 Aliens Statute does not provide for visas on humanitarian grounds in Brazil. Brazilian authorities were thus challenged to develop an effective system of protection for refugees and forced migrants, a system in compliance with international human rights and humanitarian law, designed to address local problems. However, the new migratory law which is being discussed in the Congress ${ }^{12}$ to replace the 1980 Aliens Statute has been criticized for being an instrument that was not the product of the public consultation organized by the Brazilian government in 2014, the National Conference on Migration and Refuge (COMIGRAR). ${ }^{13}$ In addition, commentators argue that the new migratory law now in Congress is not as comprehensive as the COMIGRAR proposal in significant ways described below and that the project misses the opportunity to create a specialized civilian agency to deal with migratory issues in Brazil. ${ }^{14}$

10 Humanitarian visas, in Brazil, have acquired a broader meaning than the traditional meaning in international humanitarian law. For the International Committee of the Red Cross, "International humanitarian law is a set of rules which seek, for humanitarian reasons, to limit the effects of armed conflict. It protects persons who are not or are no longer participating in the hostilities and restricts the means and methods of warfare. International humanitarian law is also known as the law of war or the law of armed conflict." (ICRC, 2007, p. 1). In Brazil, humanitarian protection can be granted not only for individuals coming from displacement caused by wars and conflicts, but also for those fleeing natural disasters and other types of generalized violence and serious human rights violations.

11 It is important to note that refugees are a category of the broader term migrant. A person can migrate voluntarily or involuntarily. As the 1951 Convention provides, a refugee is a forced migrant who migrates due to a well-founded fear of persecution "because of his/ her race, religion, nationality, membership in a particular social group or political opinion". A refugee is always a forced migrant, but a forced migrant does not always fulfill the requirements above mentioned to be qualified as a refugee. On the matter of the refugee definition, see, e.g., GOODWIN-GILL, LAMBERT (2010, pp. 26, 36, 38, 39, 43-47, 51 and 72) and HATHAWAY (2005, pp. 7, 61 and112).

12 The Draft Articles N. 288/13 (in Portuguese, Projeto de Lei № 288/13) were proposed on $11^{\text {th }}$ July 2013 by Senator Aloysio Nunes Ferreira. On the $2^{\text {nd }}$ of July 2015 the draft was voted and approved by the Foreign Relations Commission at the Senate, in Brasilia. It is now waiting for approval in the Congress. The project is likely to be approved since the government and the opposition reached an agreement on the necessity of implementing a new migratory framework in Brazil. The process is currently at the Chamber of Deputies, in Brasilia under the number PL 2516/2015. (RODRIGUES, 2015). For the whole text of the Draft Articles N. 288/13, see http://www25.senado.leg.br/web/atividade/materias/-/materia/113700 .

13 For information on COMIGRAR see http://www.participa.br/comigrar\#.VeR2wXi5ucc; and footnote 28 .

14 Although advancing in many aspects, the Brazilian Migration Statute (Draft Articles 288/13) "establishes the [migrants] rights vaguely, without acting on structural conditions that promote 
This article attempts to provide a panoramic view of the developments in refugee and migratory law in Brazil in the last 20 years. In doing so it will briefly present the international and regional refugee protection framework and analyze how those systems influenced Brazil in the establishment of its own refugee and forced migrant protection framework. Part 1 will address the classic definition of refugee expressed in the 1951 Convention and its limitations. Part 2 will provide a background for the Cartagena Declaration in order to present its enlarged refugee definition and its system of updates. Finally, Part 3 will analyze the definitions provided by the Brazilian Refugee Statute and complementary protection systems of humanitarian visas in order to examine the practices Brazil is applying to new influxes of forced migrants such as Haitians, and the eligibility mechanisms adopted by national law and regulations.

\section{BACKgROUND AND DEFINITIONS OF INTERNATIONAL REFUgEe LAW}

Refugee law was a creation of European political culture, first designed after World War II by European countries in order to protect refugees from Europe (HATHAWAY, 2010, p.70). However, even before that, as governments were interested in pursuing their own goals, displaced persons used to be seen as enriching society. There were, therefore, incentives for people to move to some countries which were in need of an enhanced labor force. This view had partially changed by the beginning of the twentieth century (HATHAWAY, 2010, p.71), when the international refugee framework was created between two opposing ideas: the principle of sovereignty and self-preservation of the State, and humanitarian principles advocated in international legal instruments (GOODWIN-GILL; MCADAM, 2007, p.1). It has been stated, however, that "current refugee law does not fully embody either humanitarian or human rights principles [and] refugee law in fact rejects the goal of comprehensive protection for all involuntary migrants and imposes only a limited duty on states, far short of meeting the needs of refugees in a comprehensive way" (HATHAWAY, 2010, p.71). States, thus, have developed policies to control borders and prevent "undesirable" people from settling within their territories. This view has made states see refugees as "unwanted children" or as a "burden"(BYRNE; SHACKNOVE, 1996, p.187) that needs to be shared among them.

Accused of being limited in its scope, the 1951 Convention definition ${ }^{15}$ provides that a refugee is any person

effective change. It does not create, for instance, a civilian agency responsible for processing migrants claims" (GUMUEIRO et. al., 2015).

15 The Convention initially applied its definition to those persons whose reasons for flight or 
who is outside his/her country of nationality or habitual residence; has a well-founded fear of persecution because of his/ her race, religion, nationality, membership of a particular social group or political opinion; and is unable or unwilling to avail himself/her self of the protection of that country, or to return there, for fear of persecution.

The five categories defined in the 1951 Convention come from negotiations and the travaux preparatoires that preceded its entry into force. Lawyers, scholars and activists criticize the narrow scope of the classical refugee definition, arguing that currently international refugee law has become distant from refugee voices and struggles (CHIMNI, 1998, p. 6). Furthermore, the 1951 Convention does not address contemporary causes of displacement such as environmental disasters, sea level rise and other effects of climate change, and different forms of persecution which are not contemplated by the Convention, such as homophobic persecution of individuals based on sexual preference or gender identity.

Those people who fall within the scope of the Convention ${ }^{16}$ are entitled to a set of rights which states signatories to the Convention must observe, such as non-discrimination, freedom of religion, gainful employment (Chapter III), welfare (Chapter IV), etc. A large number of displaced persons are not entitled to the 1951 Convention's protection as they do not fulfill the requirements of the classical refugee definition. To solve this problem states have implemented in their national legislation the so-called "complementary protection instruments". In Europe, for instance, two Directives constitute the complementary protection framework, the Qualification Directive ${ }^{17}$ and the Temporary Protection

displacement lay in events occurring before 1 January 1951; this limitation was later removed through the adoption of the 1967 Protocol to the 1951 Convention. "Protocol Relating to the Status of Refugees," 1967: 606 UNTS 267.

16 Some individuals are affected by exclusion grounds provided in the 1951 Convention. Articles $1 \mathrm{D}, 1 \mathrm{E}$ and $1 \mathrm{~F}$ of the 1951 Convention provide exclusion clauses for people who, although they are within the definition of refugee, "may be excluded from international protection because they are receiving protection or assistance from a UN agency other than UNHCR or because they are considered undeserving of international refugee protection on account of certain serious criminal acts". See United Nations, United Nation High Commissioner for Refugees, Department of International Protection. Refugee Status Determination. Who is entitled to refugee status? Geneva, 2005. p 76.

17 EUROPEAN UNION. Council Directive n. 2005/85/EC of $1^{\text {st }}$ December of 2005. European Council. Available at: http://eur-lex.europa.eu/LexUriServ/LexUriServ. do?uri=OJ:L:2005:326:0013:0034:EN:PDF. Accessed 25 jul. 2015. Before 2004, the year of the implementation of the Qualification Directive, Member States operated under ad hoc criteria for granting subsidiary protection. The necessity of harmonization in the Common European 
Directive $^{18}$. In Latin America, as the integration process is not at the EU level, each State may develop in domestic law its own instruments for complementary protection of forced migrants not recognized as refugees ${ }^{19}$. In Brazil, as it will be seen below, the government has established a visa granted on humanitarian grounds for people entitled to complementary protection. MCADAM (2007, p. 57) highlights that:

\section{however properly the refugee definition contained in the 1951 Convention may be applied, there are}

Asylum System led to the implementation of the Qualification Directive. It also aimed to create a common definition for refugees within the scope of the 1951 Convention.

18 EUROPEAN UNION. Council Directive n. 2001/55/EC of 20 July 2001. European Council. Available at: http://europa.eu/legislation_summaries/justice_freedom_security/free movement_of_persons_asylum_immigration/133124_en.htm. Accessed 25 jul. 2015.

19 The year of 2014 marked a dramatic increase in massive flows of migrants to European shores, especially those fleeing the Syrian conflict. In order to deal with this protracted situation, Europe has implemented the European Agenda on Migration of 13 May 2015. The Agenda supports the aim of establishing a common approach among Member States to deal with migration and refugee flows. It states that: "This [Agenda] calls for a set of core measures and a consistent and clear common policy. We need to restore confidence in our ability to bring together European and national efforts to address migration, to meet our international and ethical obligations and to work together in an effective way, in accordance with the principles of solidarity and shared responsibility. No Member State can effectively address migration alone. It is clear that we need a new, more European approach. This requires using all policies and tools at our disposal - combining internal and external policies to best effect. All actors: Member States, EU institutions, international organisations, civil society, local authorities and third countries need to work together to make a common European migration policy a reality." (EUROPEAN COMMISSION, 2015, p. 2).

The New York City Bar Association and its European Affairs Committee expressed support for the European Migration Agenda in a letter to EU and UN officials dated July 22, 2015, where they "strongly support these emergency measures and urge Member States of the European Union to accept responsibilities and make new commitments for these provisional measures. We also urge implementation of the European Agenda on Migration. Longer-term changes in the system for receiving and processing asylum applicants in a more humane, consistent and transparent manner are necessary. A better structure for dealing with those seeking refuge inside the European Union who are in clear need of protection, and assisting in their integration into European society, is essential. Furthermore, the Committee is of the opinion that the Agenda's focus on EU-wide standards and procedures, rather than the current differentiated approaches in Member States, is both consistent with fundamental rights in the European Union and necessary to address a problem that cannot be solved at the Member State level. Such a solution is consistent with the principles of solidarity, subsidiarity, proportionality, and fair sharing of responsibility." It is important to note that this letter from a respected bar association with a long record of involvement in international law highlighted an EUwide common approach towards migration as a solution to the disastrous effects of the lack of harmonization on subjects such as reception conditions, qualification as a refugee, processing of asylum applications, procedural and other issues. (THE ASSOCIATION OF THE BAR OF THE CITY OF NEW YORK, 2015, p. 2). 
some categories of persons in need of protection who do not fall under the strict scope of these instruments. Such refugees of concern to UNHCR include, for example, thosefleeing the indiscriminate effects of violence arising in situations of armed conflicts with no specific element of persecution. UNHCR has accordingly promoted the adoption of complementary or subsidiary regimes of protection to address their needs.

As to the above mentioned assumption, it needs to be clarified that persons falling outside the scope of the 1951 Convention are not technically considered refugees in the view of the United Nations High Commissioner for Refugees (UNHCR). Complementary or subsidiary systems of protection are based on the assumption of complementarity among human rights, humanitarian and refugee law (CANÇADO TRINDADE, 2004, p. 5). Those systems are within the scope of national legislation, designed to protect individuals who cannot be sent back to places where they are at risk of being tortured, due to the principle of non-refoulement, but who do not qualify as refugees.

Whatever the level of sovereignty states possess in deciding immigration issues within the limits of their territory, when dealing specifically with asylum seekers and refugees ${ }^{20}$ they are bound by the principle of non-refoulement, which provides that no person should be expelled or returned to a country where she or he is at risk of facing torture, degrading or inhuman treatment. Established at the international level by Art. 33 of the 1951 Convention and its 1967 Protocol and by Art. 3 of the 1984 Convention Against Torture, and at the regional level by the $5^{\text {th }}$ Conclusion of the 1984 Cartagena Declaration, the principle of non-refoulement has partially mitigated state sovereignty and has granted protection to individuals who do not possess refugee status. Non-refoulement has acquired a jus cogens nature, especially when it comes to protection and prevention of torture, by virtue of Art. 3 of the Convention Against Torture (ALLAIN, 2001, p. 537). The growing importance of non-refoulement in international human rights and refugee law has influenced the creation of complementary protection systems by states, since a person at risk of suffering torture in his or her country of origin or in a third country cannot be returned even if the person does not qualify as a refugee.

There is a tension between the idea of creating complementary

20 "Asylum seekers" are defined as individuals who have already applied for refuge whose proceeding is still pending a final decision. A refugee, on the other hand, is an individual whose application has been decided and who has been recognized as a refugee. Both asylum seekers and refugees are "people of concern" of the UNHCR. 
systems of protection on the one hand and expanding the definition of refugee on the other hand. Currently, states may adopt complementary or subsidiary mechanisms even when the individual is entitled to international protection granted by the 1951 Convention regime. Complementary protection systems are accused of impairing the application of the classical definition of refugee. Some countries are accused of interpreting the Convention definition extremely narrowly in order to provide subsidiary protection to the majority of applicants for international protection, since complementary protection systems are regulated outside any international law regime, are subject to greater domestic discretion, and frequently provide a lower level of protection (MCADAM, 2006, p. 55).

\section{Latin American Refugee Framework and the 1984 Cartagena DECLARATION}

Latin America has faced waves of migration during the past. The Colombian violence, for example, has led to the flight of millions of people, some of whom have crossed international borders, and others of whom have moved to safer regions within the territory of the country where they currently constitute 5.7 million internally displaced people (IDPs) $^{21}$. The Latin American context, therefore, demanded a rethinking of the refugee law and the types of protection granted individuals in the context of forced migration, since the classical definition of refugee could not properly address regional waves of migrants due to its limited scope. ARBOLEDA (2006, p. 185) states that:

The internationally accepted refugee definition has proven inadequate to deal with the problems posed by the millions of externally displaced persons in the third world. African and Central American countries, in particular, have experienced massive influxes of people fleeing to neighboring countries, owing to combinations of war, political instability, internal civil strife, economic turmoil, and natural disasters.

The classical definition, as ARBOLEDA notes, is inadequate as it does not provide protection for people persecuted for reasons

21 "According to official figures of 30 June 2014, more than 5.7 million people have been internally displaced in Colombia since the start of recording official cumulative registration figures; more than 64,500 people were officially declared displaced during the first half of 2014 and were awaiting registration; and almost 24,000 people were officially registered by the national Victims Unit." UNHCR. 2105 UNHCR country operations profile - Colombia | Overview |. Available at: http://www.unhcr.org/pages/49e492ad6.html. Accessed on 22 jul. 2015. 
different from those provided in the 1951 Refugee Convention. It does not encompass, for example, cases where individuals have to leave their countries due to natural disasters, effects of climate change, genderbased violence or internal conflicts, among other reasons.

Broader definitions have been adopted in different regions, mainly in the global South, in order to deal with local issues on migration and refuge. The first continent to adopt an expanded concept of refugee was Africa. In 1969, the Organization of African Unity Convention Governing the Specific Aspects of Refugee Problems in Africa was adopted, the definition of refugee provided in Art. 1 of that binding legal instrument states as follows:

The term 'refugee' shall also apply (in addition to the 1951 Convention) to every person who, owing to external aggression, occupation, foreign domination or events seriously disturbing public order in either part or the whole of his country of origin or nationality, is compelled to leave his place of habitual residence in order to seek refuge in another place outside his country of origin or nationality. (OAU CONVENTION, 1969).

This definition was adopted as it more closely reflected the realities of Africa during a period of violent struggle for self-determination and national development (ARBOLEDA, 2006, p. 186). The OAU Convention created a binding legal instrument designed to deal with refugee problems arising from the African reality. It added to the grounds for protection granted by the 1951 Convention and made explicit the necessity of reviewing refugee protection at the international level. The OAU Convention influenced states in other parts of the world to elaborate legal instruments that could better address the plight of refugees in today's world.

Inspired by the OAU Convention, Latin American states also discussed the enlargement of the definition of refugee within their region. The 1981 Colloquium on Asylum and International Protection of Refugees in Latin America ${ }^{22}$ discussed the inadequacy and incongruencies of refugee law and protection in the context of the Central American crisis. The displacement produced in the continent did not have the same nature as the European displacement due to World War II, which gave rise to the classical refugee definition in the 1951 Convention. Latin American refugees were fleeing situations of generalized violence, massive human rights violations, situations of aggression and internal conflicts.

22 The Colloquium was convened by the Mexican Secretary of Foreign Affairs in co-operation with the Institute for Legal Research of the National University of Mexico under the auspices of the UNHCR, aiming to address the Central American crisis and its displacement of people. 
In 1984, Latin American countries agreed to implement a soft law ${ }^{23}$ non-binding instrument that expanded the definition of refugee ${ }^{24}$. The third conclusion of the newly adopted Cartagena Declaration provided that in addition to the protection granted by the 1951 Convention, the definition of "refugee" would include persons against whom there

\section{exist a threat to life, security, or liberty; and that the threat result from one of five factors: generalized violence; foreign aggression; international conflicts; massive violations of human rights; or circumstances seriously disturbing public order. (OAS, 1984 Cartagena Declaration, 1984)}

The enlarged refugee definition expressed in the Cartagena Declaration highlighted the generous tradition rooted in Latin American law regarding the granting of asylum, as well as a pragmatic approach resulting from the analysis of migration flows in the continent (ARBOLEDA, 2006, p. 199).

Since the circumstances and nature of refugees and migration fluxes change and evolve, the Cartagena Declaration was designed so it could be updated every ten years. In 1994, the San José Declaration, celebrating the $10^{\text {th }}$ anniversary of the Cartagena Declaration, paid special attention to the idea of complementarity among three strands of international human rights law: human rights law, humanitarian law and refugee law. In this light, the tenth conclusion established that "both refugees and people who migrate for other reasons, including economic ones, have human rights which must be respected at all times, circumstances or places" (OAS, San Jose Declaration, 1994). It also reaffirmed the relation of complementarity in the Latin American refugee framework and the rules of international humanitarian law and

23 "Soft law" refers to declarations of international conferences, resolutions of the United Nations General Assembly, decisions and resolutions of human rights bodies, and other groups of civil society and governments which is technically not binding international law but which represents a level of consensus on what the law should be and is becoming. Soft law may become binding international law through its use by states and be recognized as customary law or be used in treaty language, which is binding on all states parties. Soft law represents a certain understanding of new law responsive to changing circumstances which carries its own moral authority and can be cited as an expression of the will of the international community in the broadest sense. (TINKER, 2015, pp. 81-93).

24 From 19-22 November of 1984, experts and representatives from ten governments (Belize, Colombia, Costa Rica, El Salvador, Guatemala, Honduras, Mexico, Nicaragua, Panama and Venezuela) met in Cartagena, Colombia, and held a Colloquium named "Coloquio Sobre la Protection Internacional de los Refugiados en America Central, Mexico y Panama: Problemas Juridicos y Humanitarios". This Colloquium culminated in the implementation of the 1984 Cartagena Declaration on Refugees. 
human rights law.

Ten years latter, the Mexican Plan of Action, established in 2004, drew attention to "durable solutions": local integration, voluntary repatriation and resettlement of refugees. As to resettlement, Brazil presented a proposal accepted by the other Latin American states: the creation of a regional system of protection, based on the principles of solidarity and burden sharing. The "Solidarity Resettlement Programme" started by protecting only those refugees who originated in the region, intended especially for Colombians; in 2007, it was extended to protect refugees from other parts of the world (WHITE, 2012, p. 7). Although the Programme is still small in scale, it has been considered an important regional tool to deal with protracted situations of displacement (OAS, San Jose Declaration, 1994).

The Brazilian Declaration (OAS, The Brazilian Declaration, 2014), established in 2014 at the "Cartagena+30" meeting, has raised important aspects as to the current causes of displacement, especially those related to persecution arising from discrimination against "lesbian, gay, bisexual, transgender and intersex people (hereinafter referred to as "LGBTI")". It is important to highlight that sexual orientation is not a ground for protection under the 1951 Convention, but the Cartagena Declaration and its enlarged definition offer a framework which encompasses this possibility.

The dynamic of the Cartagena Declaration and its process of expansion of the scope of protection of refugees has offered states the possibility to extend the 1951 Convention's classical definition of refugee to grant refugee status within Latin America to individuals persecuted on grounds other than those provided by the 1951 Convention. The next section will address how Brazil implemented the Cartagena Declaration in its domestic legislation and how the protection of refugees is interrelated with migration law in that country.

\section{Brazilian Migratory and Refugee Framework and THE DeFINITION OF "REFUGEE" IN DOMESTIC LAW}

In 1997, Brazilian legislators enacted the new Refugee Statute. This legislation, based on the 1951 Convention, contained important innovations, especially regarding the refugee definition. Article 1 of the Statute provides that:

Will be recognized as a refugee every individual who:

I - due to well-founded fear of persecution for reasons of race, religion, nationality, social group or political opinion find themselves outside their 
country of nationality and can not or will not rely on the protection of that country;

II - not having a nationality and being outside the country where once had his habitual residence, is unable or unwilling to return to it, under the circumstances described in the preceding item;

\section{III - due to serious and widespread violations of human rights, is obliged to leave their country of nationality to seek refuge in another country. (BRAZIL, 1997) [emphasis added]}

Item III of Art. 1 of the Statue includes in the Brazilian framework a new ground for protection in addition to those provided in the classical definition of refugee. The expression "serious and widespread violations of human rights" was taken from the enlarged definition in the Cartagena Declaration and included in Art. 1 of the Brazilian Refugee Statute. By adding this important element to domestic law, Brazil has given binding legal force to the non-binding Cartagena Declaration on this point. The UNHCR representative in Brazil, Andres Ramirez, has stated in an interview (SILVA, 2012, p.170) that the Brazilian Refugee Statute is:

one of the most advanced. It is a very important tool for the protection of refugees in Brazil [...] I've worked in many countries and recognize that the law is one of the most advanced in the world, it is cutting edge [...] the Brazilian law has incorporated the 1951 Convention and important aspects of the 1984 Cartagena Declaration for [...] the widespread violation of human rights. ${ }^{25}$ (our translation)

It is true, indeed, that Brazil has enlarged the definition of refugee giving binding force to an section of the Cartagena Declaration. It can be argued, however, that Brazilian legislators lost the opportunity to expand the refugee definition even more within its territory. Important

25 "A lei foi pioneira sobre refúgio, uma das mais avançadas em nível internacional. É uma ferramenta de grande importância para a proteção dos refugiados aqui no Brasil [...]eu que já trabalhei em muitos países do mundo, reconheço que a lei é uma das mais avançadas no mundo, é de vanguarda [...]. o Brasil incorporou na lei a Convenção da ONU de 1951 e aspectos importantes da Declaração de Cartagena de 1984[...]como a violação generalizada de direitos humanos.” SILVA, Cesar Augusto Silva da. A Política Brasileira para Refugiados (1998-2012). p. 170. 
aspects of refugees' realities presented in the Declaration's definition, such as generalized violence, foreign aggression, international conflicts and events seriously disturbing public order, were not included in the Brazilian Refugee Statute of 1997.

Although Brazil has one of the most advanced legislations in the world on refugee protection, its framework on complementary protection for people in situations of forced migration who do not qualify as refugees is rudimentary at best, especially if compared to the European system as noted above. It lacks consistency and binding force and relies heavily on the discretionary power of administrative bodies.

The complementary protection mechanism was developed in 2010 in Brazil to address the massive influx of Haitians across the northern border of Brazil. The country established an ad hoc mechanism for granting humanitarian visas through the National Immigration Council (CNIg). The process is discretionary and the analysis made by the CNIg members emphasizes the needs of the Brazilian labor market instead of prioritizing humanitarian issues ${ }^{26}$.

This system was designed to address those migrants who could not be sent back to their countries of origin due to humanitarian reasons based on the principle of non-refoulement, but who would not otherwise be recognized as refugees ${ }^{27}$. Resolution n. 97, implemented in 2012,

26 It is important to consider the structure and composition of CNIg, as it is decisive for the kind of analysis it makes of the humanitarian visa applications. This body is within the Brazilian Ministry of Labor and Employment and is chaired by its representative. The members of CNIg are representatives of the Ministries of Justice, Foreign Affairs, Agriculture, Science and Technology; four representatives of the Workers Unions; four representatives from the employers; and a representative of the scientific community. According to its charter, the body's duties are, among others: I. To formulate goals for the development of immigration policy; II. To coordinate and guide the immigration activities; III. To promote studies related to immigration issues; IV. To analyze periodically the need for foreign qualified labor force; V.To establish immigrant selection rules. (our translation). Since the body (CNIg) has the competence to design and implement immigration policies, it has the prerogative to establish rules on the selection of migrants who will be accepted in the country. This context makes the decision, which should be taken mainly regarding humanitarian values, to be fundamentally taken to meet the domestic labor market needs. The relationship between immigration law and the labor market ("modern-day slavery") has been critiqued by US scholars such as Chantal Thomas. See THOMAS (2013, p. 13-86).

27 The humanitarian visa provided by Resolution n. 97 may be renewed for the same period (five years) if the migrant can prove he is legally working in the country. For further information see: CHAGAS, Marcos. CNIg prorroga prazo para a concessão de visto humanitário aos haitianos. Agência Brasil. dez. 2014. Available at:http://www.ebc.com.br/cidadania/2014/12/ cnig-prorroga. Accessed on 20 Oct. 2015. The PLS N. 288/13 provides the humanitarian visa would be granted for a period of 1 (one) year only, renewable for 1 (one) year, if the humanitaria reasons for the concession persist. For further information see: art. $5^{\circ}$ of the Draft Articles PLS N. 288/13. Available at http://www25.senado.leg.br/web/atividade/materias/-/materia/113700. 
provided that:

Art. 1 Individuals from Haiti will be granted a permanent visa provided in Art. 16 of the 6.815 Statute, of August 19, 1980 (The Aliens Statute) for humanitarian reasons, for a period of 5 (five) years, pursuant to Art. 18 of the same law, a circumstance which will be mentioned in their Foreigner Identity Card.

Single paragraph. Humanitarian reasons, for the purpose of this Resolution, are those resulting arising from the deterioration of the living conditions of the Haitian population as a result of the earthquake in that country on January 12, 2010. (our translation)

This Resolution in 2012 established the complementary system in Brazil, which was necessary since the 1980 Aliens Statute ${ }^{28}$ did not address that possibility. The Resolution imposed numerical and geographical limitations for granting humanitarian protection in Brazil, such that only 100 visas per month would be permitted for Haitians. This measure resulted in a huge number of individuals coming to Brazil from Haiti and elsewhere with no valid documents, often being smuggled in by coyotes and illegal networks of traffickers (SILVA, 2013, p. 221).

Finally, in 2013, the CNIg implemented a new Resolution ending the numerical limitation. Resolution n. 102 was based on the presumption that the Haitian migration would not be a limited phenomena and should be addressed in a more comprehensive way. It is important to explain the refugee protection system in Brazil, as it is closely related to the humanitarian visa, which is an embryonic complementary protection scheme for forced migrants who do not

Accessed on 12 Aug. 2015.

28 In 1980, during the final years of the dictatorship in Brazil, before the establishment of the 1988 Brazilian Constitution, the government enacted the 1980 Aliens Statute. This legislation was heavily based in the National Security Doctrine, a theory that presented aliens as enemies of the State and provided no guarantees for those individuals. "The axiology of the Aliens Statute supports the recurrent ideology of authoritarian regimes, seeing the alien as someone who undermines social cohesion, brings anarchy and subversion, an individual considered dangerous to the country. For this reason, the arrival and the stay of foreigners in the country has become an exception, depending on the needs of the labor market and on national security ideas." (MILESI, 2009, p. 58) (our translation). 
qualify as refugees under the Refugee Statute. The humanitarian visa protects Haitian migrants from forcible return to their country of origin by recognizing the principle of non-refoulement, but does not grant them full protection as refugees, as explained below.

The governmental body responsible for the reception of migrants in Brazil is the Federal Police, and an individual seeking to apply for refugee protection should make a formal request to the Federal Police as soon as he or she enters into Brazilian territory. This request is forwarded to the National Council for Refugees (CONARE), an agency created by the 1997 Refugee Statute and linked to the Ministry of Justice, which has jurisdiction to decide applications for refugee status in Brazil. As an applicant, the person will receive temporary documents that guarantee the enjoyment of some rights such as the right to work, public health benefits, and the right to free movement within the country's territory, among others ${ }^{29}$. CONARE and the UNHCR will then conduct the eligibility interview with the applicant and grant a first instance decision ${ }^{30}$. The applicant may appeal from a negative decision to the Ministry of Justice, which will grant a final decision on the matter. A denial of refugee status will require the migrant to leave the country in fifteen days. This is the ordinary procedure for refugee applications in Brazil, and CONARE's decisions on the applications will basically follow the 1951 Convention and the Brazilian Refugee Statute.

With the massive influx of Haitian migrants in Brazil ${ }^{31}$, a new form of protection had to be designed to encompass this situation since, according to CONARE's understanding, the classical definition of refugee did not apply to Haitians. As in Europe, when policies that made up the complementary system in that continent were formulated, also in Brazil there was a risk of violation of the principle of nonrefoulement if migrants were returned to the Haiti because of the situation of generalized violence ${ }^{32}$ existing in that country.

29 BRAZIL, 1997, Refugee Statute, Art. $6^{\circ}$.

30 Ibidem, Art. 12, II.

31 The earthquake in Haiti in 2010 killed around 200.000 people and displaced nearly 10 million, in a country that was already struggling economically and socially. The disaster only worsened the living conditions of citizens, especially after the earthquake destroyed the capital of Port-au-Prince. The UN reported that in only 35 seconds the whole country was destroyed, more than 300.000 buildings collapsed including many governmental buildings and the UN headquarters, and all the infrastructure of the country disappeared. (UNITED NATIONS, 2015).

32 For more on the concept of generalized violence see: GENEVA ACADEMY. What amounts to "serious violations of international human rights law?" An analysis of practice and expert opinion for the purpose of the 2013 Arms Trade Treaty, Academy Briefing, n. 6. August, 2004. Available at: http://www.geneva-academy.ch/docs/publications/Briefings $\% 20$ and $\% 20 I n \% 20$ breifs/Briefing $\% 206 \% 20$ What $\% 20$ is $\% 20 a \% 20$ serious $\% 20$ violation $\% 20$ of $\% 20$ human $\% 20$ 
The violation of human rights in Haiti was serious and widespread, institutions were destroyed and much of the population lost their houses and most of their livelihoods. Short term solutions were implemented and shelters were built, but after five years people are still homeless. Amnesty International published a report in 2014 stating that internally displaced people were being evicted from the displacement camps ${ }^{33}$. The Haitian influx to Brazil showed that the country needed an update to its Aliens Statute, which did not properly address this situation.

In 2014 the Brazilian government put a lot of effort into the construction of a new law for migrants, calling on civil society, academia, non-governmental organizations and migrants themselves to participate in the $1^{\text {st }}$ National Conference on Migration and Refuge $(\text { COMIGRAR) })^{34}$, held from 30 May to $1^{\text {st } J u n e ~ 2014, ~ i n ~ S a ̃ o ~ P a u l o . ~ T h i s ~}$ Conference was a landmark in addressing migration and refugee issues in Brazil both for the wide range of people and organizations involved in the discussion and for the diversity of issues addressed during the conference. An innovative on-line discussion platform allowed persons from most parts of the country to have a say in the development of the law and policies on migration in Brazil.

At the end of the COMIGRAR, a group of specialists on migration invited by the Ministry of Justice presented a draft of the new legislation that would replace the controversial Aliens Statute (BRAZIL, 2014). This draft provided for an institutionalized regime of complementary protection. Chapter $\mathrm{X}$ of the draft provided for a mechanism of "humanitarian reception". It mentioned that:

Art. 27. In addition to the protection offered by asylum and refuge, it may be granted a visa for humanitarian purposes in cases where public order or the social peace is threatened, in countries of

rights\%20law_Academy\%20Briefing\%20No\%206.pdf. Accessed in 13 jul 2015..

33 "It is estimated that more than 170,000 people still live in more than 300 camps for displaced people, in most cases in appalling conditions, without access to essential basic services such as clean water, sanitation or waste disposal. While the disastrous sanitary conditions leave them at risk of cholera and other diseases, lack of adequate shelter makes them vulnerable to flooding and other adverse weather conditions, especially during hurricane season." (AMNESTY INTERNATIONAL, 2015, p. 21).

34 The national phase of COMIGRAR was attended by 788 people, including 232 observers, 556 delegates from 30 nationalities of 21 Brazilian states, 65 volunteers and 22 media outlets. Delegates were elected among migrants, refugees, scholars, public servants and professionals involved in the subject. Before the national phase of Comigrar, 202 preparatory conferences were held, with the participation of organizations and social movements (45\%); the academic community (16\%), Brazilians living abroad (13\%); the government (11\%); foreigners in Brazil $(5 \%)$ and others $(10 \%)$. A total of 2,840 proposals elaborated by 5,374 participants were referred to the national phase. (UNODC, 2014). 
origin, by

I - serious and imminent institutional instability;

II - disaster of major proportions;

III - serious human rights violations. (BRAZIL, 2014) [emphasis added]

This provision would take humanitarian protection away from the ad hoc mechanism and provide more efficiency and efficacy in the application of this new system in Brazil. It would address the situation of Haitians in Brazil as well as individuals from other nationalities when they apply for humanitarian protection. It would also create a net of protection, in addition to the mechanisms for refuge and asylum, in order to encompass a diverse range of individuals in need of assistance. Most important, this law would establish a civil border agency which would replace the Federal Police in the reception of migrants and refugees.

This draft, however, was never discussed in the Congress. It was replaced by another draft, which also creates a humanitarian visa, but designs it as a temporary protection scheme and does not formulate any grounds for protection, leaving the decision solely up to the discretion of the migration authorities. On the $2^{\text {nd }}$ of July 2015 this second draft was voted and approved by the Foreign Relations Commission at the Senate in Brasilia. The most important aspect of this draft is the provision for a humanitarian visa for individuals from any nationality, eliminating the limitation applied in the ad hoc system which granted humanitarian visas intended when it was adopted for Haitians only.

Despite the crucial importance of the development of a complementary protection scheme, its application to Haitians in Brazil illustrates the preferences of states and international organizations in granting weaker subsidiary protection rather than recognition of full refugee status for individuals. It is important to reiterate that refugee status is based on a binding legal instrument, the 1951 Convention, and guarantees of protection provided by the UNHCR, since refugees and asylum seekers are "persons of concern" of the agency. In addition, refugee status is permanent, unless the causes that gave rise to the individual's flight from his or her country of nationality cease, or unless there are serious reasons for considering that he or she has committed one of the crimes provided in Art. 1(f) of the 1951 Convention. There is, thus, a strong protection regime for refugees and asylum seekers under international law. The complementary systems, on the other hand, are granted by national Resolutions. States have discretion in deciding on the numbers and the nationalities of persons who will be granted 
complementary protection. States are responsible for providing social assistance and integrating those individuals within the receiving society. Once states have determined to offer complementary protection to individuals, they are not "persons of concern" of the UNHCR and are not otherwise protected by international refugee law.

Article 1(III) of the Brazilian Refugee Statute, inspired by the Declaration of Cartagena which extended the definition of refugee in Latin America, defines a refugee as one who "due to serious and widespread violations of human rights" is obliged to leave his or her country of nationality to seek refuge in another country. Accordingly, a refugee in the Brazilian system is not only a person protected by the 1951 Convention, but also a person who is in a situation of widespread violence in his or her home state. Haitian migrants, in the scenario described above after the earthquake, qualify as refugees under Brazilian law according to the Refugee Statute, but the political choice of the Brazilian authorities has been to grant complementary protection to migrants from Haiti instead.

One must restate the necessity of a framework of complementary protection in a situation where the classical definition of refugee, the only one universally accepted and binding, has such a narrow content. Modern forms of displacement, such as those caused by environmental issues and those which have grounds of persecution other than the five categories provided by the 1951 Convention, must be matched by new grounds for protection, such as the complementary system which takes into account human rights instruments as well as humanitarian law in order to protect more people from violations of human rights and generalized violence. CANÇADO TRINDADE (2004, p. 27) argues that these three branches of public international law have had, until recently, a compartmentalized application to the subject of human protection. Further, the modern doctrine of human rights seeks a convergence in normative, hermeneutical and operational levels in order to provide a broader protection for those who are in a situation of forced migration but do not fall into the category of refugees, forcing a rethinking, both nationally and international, of the limits of the definition of refugee.

Those systems of complementary or subsidiary protection should not, however, void the international refugee protection regime created by the 1951 Refugee Convention and the most progressive domestic regimes. In other words, an individual should not be granted subsidiary protection if he or she qualifies as a refugee, especially because refugee protection is more robust and permanent than the non-harmonized complementary protection systems dependent on national rather than international law. 


\section{Conclusions}

Refugee law and protection requires a rethinking, especially regarding the classical definition of refugee provided in the 1951 Convention. Modern forced flows of people are not protected by the restricted categories defined in the 1951 Refugee Convention. There is now a growing consensus on an enlargement of the definition of "refugee" at the international level.

Regional agreements and domestic law have implemented expanded definitions of "refugee" and have created a framework of complementary protection for forced migrants who do not otherwise qualify as refugees. The OAU Convention on Refugees was the first regional instrument to enlarge the refugee definition and it is still the only binding regional convention to do so.

Latin America has also expanded the definition of refugee. The 1984 Cartagena Declaration has provided for an extremely generous refugee framework, following the regional tradition of protecting people in need. Another innovation in the Cartagena Declaration is its dynamic system, requiring an update every ten years. Since its creation, the Declaration has had three updates which have addressed some of the most current problems of refugee protection. The Cartagena Declaration also focuses on local issues, such as the problems of refugees in Central America and the protracted conflict in Colombia.

Inspired by the Cartagena Declaration, Brazil established its Refugee Statute in 1997, which implemented in domestic law important concepts from the Cartagena Declaration such as adding the "serious and widespread violation of human rights" as a ground for refugee protection to those provided in the 1951 Refugee Convention. Seen as creating one of the most advanced refugee protection regimes in the world, Brazil has nevertheless been criticized for its migratory framework which can be used to grant humanitarian visas to persons who better fit Brazil's expanded definition of "refugee" and who are thus denied the full protection of the Refugee Statute.

Brazil's Aliens Statute of 1980, a law created during the dictatorship, does not address issues such as torture as grounds for humanitarian protection of migrants. More recently, Brazil has administratively designed an ad hoc framework of complementary protection for forced migrants who do not qualify as refugees, such as Haitians who have migrated to Brazil since the disastrous 2010 earthquake. This framework is based on humanitarian factors and respects the principle of non-refoulement, a cornerstone of the refugee protection regime. In July 2015 the Senate in Brazil approved the new Migratory Law and, should it be approved by the National Congress, it will replace the 1980 Aliens Statute. This law, among 
other modifications, will create an institutionalized complementary protection regime based on humanitarian protection grounds, which include serious and imminent institutional instability, armed conflicts, calamities of great proportions, serious human rights violations and humanitarian law violations. These grounds were proposed to cover situations not encompassed by the 1997 Refugee Statute and to address the legal limbo generated by the limitations of the narrow classical definition of refugee.

The complementary protection regime is extremely important in cases where the narrow classical refugee definition found in the 1951 Convention and the enlarged but non-binding definition provided by the Cartagena Declaration are not enough to protect forced migrants who cannot be refouled to their countries of origin. However, sometimes it can jeopardize the more robust international protection afforded refugees when some states categorize as humanitarian migrants those who would otherwise qualify as refugees. This distinction matters because, as seen above, different rights are granted to each group.

The case of Haitian migrants in Brazil is an example of the dubious implementation of complementary regimes of protection of forced migrants which grant temporary humanitarian visas in lieu of recognition of refugee status. The circumstances in Haiti since 2010 have created an environment of constant and serious violation of human rights in that country. Recognizing Haitians as meeting the definition of refugee under the 1997 Refugee Law is appropriate, since Item III of Art. 1 of the Refugee Statute includes "serious and widespread violations of human rights" as grounds for granting refuge in Brazil. Should Brazil apply its Refugee Statute to Haitians, the international community will be enabled to act through the UNHCR, which can provide assistance and international protection only for persons recognized as refugees. While Haitian migrants in Brazil cannot be returned to Haiti under Brazilian law, which recognizes the principle of non-refoulement, they should more properly be classified as refugees and given greater protections.

\section{BibLIOGRAPHY}

ACNUR. Declaração de Cartagena de 1984. Available at: http:// www.acnur.org/t3/fileadmin/Documentos/portugues/BD_Legal/ Instrumentos_Internacionais/Declaracao_de_Cartagena.pdf? - view=1. Accessed on $\overline{10}$ jul. 2015.

ALLAIN, Jean. The jus cogens nature of non-refoulement. International Journal of Refugee Law. Oxford: Oxford University Press, 2001, v. 13, n. 04. pp. 533-588.

ALMEIDA, Guilherme Assis de. A Lei 9474/97 e a definição ampliada 
de refugiado: breves considerações. In: ALMEIDA, Guilherme Assis de; ARAÚJO, Nádia de. O Direito Internacional dos Refugiados - Uma Perspectiva Brasileira. Rio de Janeiro: Renovar, 2001, pp. 155-167.

AMNESTY INTERNATIONAL. '15 minute to leave'. Denial of the right to adequate housing in post-quake Haiti. 2015, 68 p.

ANDRADE, José Henrique Fischel de. O Brasil e a Organização Internacional para os Refugiados (1946-1952). Revista Brasileira de Política Internacional. Brasília, V. 48, n.1, jun 2005. Available at: http://www.scielo.br/scielo.php?s cript=sci_arttext\&pid $=\mathrm{S} 0034-73292005000100003$. Accessed on 10 jul. 2015 .

- A Política de Proteção a Refugiados da Organização das Nações Unidas - Sua Gênese no Periodo Pós-Guerra (1946-1952). Tese (Doutorado em Relações Internacionais). Universidade Nacional de Brasília, Instituto de Relações Internacionais. Brasília/DF, UNB, 2006.

ARBOLEDA, Eduardo. Refugee Definition in Africa and Latin America: The Lessons of Abstract Pragmatism. International Journal of Refugee Law. Oxford: Oxford University Press, 1991, v. 3, n. 2. pp. 186-207.

ARBOLEDA, Eduardo; HOY, Ian. The Convention Refugee Definition in the West: Disharmony of Interpretation and Application. International Journal of Refugee Law. Oxford: Oxford University Press, 1991, v. 5, n. 1. pp. 66-90.

BRASIL. Lei no 9.474 de 22 de Julho de 1997. Define mecanismos para a implementação do Estatuto dos Refugiados de 1951, e determina outras providências. $A C N U R$. Available at: http://www.acnur.org/t3/fileadmin/ scripts/doc.php? file $=\mathrm{t} 3 /$ fileadmin/Documentos/BDL/2002/0801. Accessed on 25 jul. 2015.

. Ministério da Justiça. Anteprojeto da Lei de Migrações de


de jul. De 2014. Available at: http://library.fes.de/pdf-files/bueros/ brasilien/10947.pdf. Accessed on 20 jul. 2015.

BYRNE, R. and SHACKNOVE, A., 'The Safe Third Country Notion in European Asylum Law', 9 Harvard Human Rights Journal, 187 (1996), p. 187.

CANÇADO TRINDADE, Antonio Augusto. Direito Internacional dos Direitos Humanos, Direito Internacional Humanitário e Direito Internacional dos Refugiados: Aproximações ou Convergencias. Direitos Humanos Net . Available at: http://www.dhnet.org.br/direitos/ $\mathrm{sip} /$ dih/didh.html. Accessed on 25 out 2014. 
CANTOR, David. James.; BARRICHELLO, Stefania Eugenia. The Inter-American human rights system: a new model for integrating refugee and complementary protection? The International Journal of Human Rights. London: Routledge, 2013 v. 17, n. 5-6. p. 689-706.

CHIMNI, B.S. The Geopolitics of Refugee Studies: a View from the South. Journal of Refugee Studies. Oxford, v.11. n. 4, 1998, pp. 350374.

. Globalization, Humanitarianism and the Erosion of Refugee Protection. Journal of Refugee Studies. Oxford, v.13, n.3, 2000, pp. 243-263.

CONVENTION AGAINST TORTURE AND OTHER CRUEL, INHUMAN OR DEGRADING TREATMENT OR PUNISHMENT, New York, 10 December 1984; entered into force 26 June 1987. 1465 U.N.T.S. 85.

CONVENTION RELATING TO THE STATUS OF REFUGEES, 28 July 1951, entered into force 22 April 1954. 189 U.N.T.S. 137 and PROTOCOL RELATING TO THE STATUS OF REFUGEES, 30 January 1967, entered into force 4 October 1967. 606 U.N.T.S. 267.

DERDERIAN, Katharine; SCHOKAERT, Lizbeth. Respostas a fluxos migratórios mistos: Uma perspectiva humanitária. Revista Internacional de Direitos Humanos. Available at: http://www.surjournal.org/ conteudos/getArtigo10.php?artigo=10,artigo_derderian.htm. Accessed on 19 Jul 2015.

DUFFY, Aiofe. Expulsion to Face Torture? Non-refoulement in International Law. International Journal of Refugee Law, Oxford: Oxford University Press, jun. 2008, v. 20, n. 3. p. 373.

EUROPEAN COMMISSION. Communication from the Commission to the European Parliament, the Council, the European Economic and Social Committee and the Committee of the Regions an European Agenda on Migration. Brussels, 13 May 2015. 22p. Available at http:// ec.europa.eu/dgs/home-affairs/what-we-do/policies/european-agendamigration/backgroundinformation/docs/communication on the european_agenda_on_migration_en.pdf. Accessed on 2 Jul. $2 \overline{0} 15$.

GOODWIN-GILL, Guy, S.; MCADAM, Jane. The refugee in international law. 3 ed. New York: Oxford University Press, 2007. 786 p.

GUMEIRO, Camila; SALUSTIANO, Hugo;ARAÚJO, Natália Lima de. Panorama Geral da Lei de Migrações Brasileira (1980-2014). Educar para o Mundo. 26 set. 2014. Available at: https://educarparaomundo. wordpress.com/category/lei-de-migracoes/. Access in: $1^{\text {st }}$ set. 2015. 
New trends in migratory and refugee law in Brazil - Tinker and Sartoretto

HATHAWAY, J. C., 'A Reconsideration of the Underlying Premise of Refugee Law' in Helene Lambert (ed), International Refugee Law (Ashgate Publishing 2010).

INTERNATIONAL COMMITTEE OF THE RED CROSS. What is International Humanitarian Law? Advisory Service on International Humanitarian Law, jul. 2007. 2p.

JUBILUT, Liliana Lyra. O direito internacional dos refugiados e sua aplicação no ordenamento jurídico brasileiro. SP: ed. Método/ UNHCR-AcNUR, 2007.

MCADAM, Jane. Complementary Protection in International Refugee Law. Oxford: Oxford University Press, 2007. 322 p.

, Jane. The Standard of Proof in Complementary Protection Cases: Comparative Approaches in North America and Europe. Critical Issues in International Refugee Law Research Workshop, Toronto, May 2008, 17 p.

ORGANIZATION OF AMERICAN STATES. San Jose Declaration on Refugees and Displaced Pearsons. San Jose, Dec. 1994. Available at: http://www.refworld.org/pdfid/4a54bc3fd.pdf. Accessed on 25 jul. 2015.

. The Brazil Declaration and Plan of Action. Brasilia, Dec. 2014. Available at: http://www.refworld.org/docid/5487065b4.html. Accessed on 20 jul. 2015.

ORGANIZAÇÃO DAS NAÇÕES UNIDAS. Convenção de 1951 Relativa ao Estatuto dos Refugiados. 28 de julho de 1951. Disponível em: http://www.pucsp.br/IIIseminariocatedrasvm/documentos/ convencao_de_1951_relativa_ao_estatuto_dos_refugiados.pdf.

ORGANIZATION OF AFRICAN UNITY. OAU Convention Governing the Specifics Aspects of Refugee Problems in Africa. Addis Ababa, Sep. 1969. Available at: http://www.unhcr.org/45dc1a682.html. Accessed on 24 jul 2015.

PIOVESAN, Flávia. Direitos Humanos e Direito Constitucional Internacional. 14. ed. São Paulo: Saraiva, 2013. 704 p.

RAMOS, Erika Pires. Refugiados Ambientais: em busca de reconhecimento pelo direito internacional. Tese (Doutorado em Direito) - Faculdade de Direito, Universidade de São Paulo, 2011. 150 p.

RODRIGUES, Edilson. Immigration Law progresses in Congress. Conectas Human Rights. Brasilia, 17 Jul. 2015. Available at: http://www. conectas.org/en/actions/foreign-policy/news/40180-immigration-lawprogresses-in-congress. Accessed on 28 aug. 2015. 
SANTIAGO, Adriana (org.). Haiti por si - a Reconquista da Independência Roubada. Fortaleza: Expressão, 2013.

SCHARPF, Fritz W. Economic integration, democracy and the welfare state. Max Planck Institute for the Study of Societies Working Paper. Leibniz, 1996, v. 02, n. 96. p. 1-19.

SILVA, Cesar Augusto Silva da. A Política Brasileira para Refugiados (1998-2012). Tese (Doutorado em Ciencia Política) - Faculdade de Ciencias Sociais, Universidade Federal do Rio Grande do Sul, Porto Alegre, 2013. 292 p.

SPIRO, Peter J., Beyond Citizenship: American Identity after Globalization, Oxford University Press, 2008.

THE ASSOCIATION OF THE BAR OF THE CITY OF NEW YORK. Support for a European Migration Agenda, New York, July 22, 2015. 3p. Available at http://www2.nycbar.org/pdf/report/uploads/7_20072947SupportforEuropeanCommissionProposalsforaCommonEuropeanMigr ationAgenda.pdf. Accessed on 06 Aug 2015.

THOMAS, Chantal. Immigration Controls and 'Modern-Day Slavery'. Cornell Legal Studies Research Paper No. 13-86. 16 Jul. 2013. Available at http://ssrn.com/abstract=2294656 orhttp://dx.doi.org/10.2139/ ssrn.2294656. Accessed on 12 jul. 2015.

TINKER, Catherine. "Creation of International 'Soft Law': Formation and Effect of the 'Sustainable Development Goals' in the post-2015 Development Agenda at the United Nations," in Globalização e as novas perspectivas no direito ambiental econômico. Cristiane Derani and Mariana Caroline Stolz, org., Curitiba, Brazil, Multideia Ed., 2015, pp. 81-93 (chapter based on symposium presentation at UFSC in March, 2014); available at http://www.multideiaeditora.com.br/flip/ globalizacaoHTML/globalizacao_index.html\#1. Accessed on 28 aug. 2015.

TURTON, David. Conceptualising Forced Migration. Refugee Studies Centre Working Paper Series. Oxford: Oxford University Press. 2003, n. 12.17 p.

UNITED NATIONS. Cinco anos depois do terremoto que destruiu o Haiti, ONU continua apoiando reconstrução do país. 12 jan. 2015. Available at: http://nacoesunidas.org/exclusivo-cinco-anos-depois-doterremoto-que-destruiu-o-haiti-onu-continua-apoiando-reconstrucaodo-pais/. Accessed on 19 jul. 2015.

UNITED NATIONS. UN General Assembly. Convention against Torture and Other Cruel, Inhuman or Degrading Treatment or Punishment. New York, 1984. Available at: A/RES/39/46, available at: 
http://www.refworld.org/docid/3b00f2224.html. Accessed on $26 \mathrm{Jul}$ 2015.

UNITED NATIONS HIGH COMMISSIONER FOR REFUGEES. Discussion Document. The Refugee Situation in Latin America: Protection and Solutions Based on the Pragmatic Approach of the Cartagena Declaration on Refugees of 1984. Discussion Document. International Journal of Refugee Law, v. 1, n. 18. Oxford, 2004. p 251270.

UNITED NATIONS HIGH COMMISSIONER FOR REFUGEES. 1951 Geneva Convention Relating to the Status of Refugee. Geneva, 1951. Available at: http://www.refworld.org/cgi-bin/texis/vtx/ rwmain?page $=$ search $\&$ docid $=3$ be 01 b $964 \&$ skip $=0 \&$ query $=1951 \% 20$ REFUGEE\%20CONVENTION. Accessed on 25 jul 2015.

UNIÃO EUROPEIA. Diretiva do Conselho 2001/55/EC de 20 de julho de 2001. Parlamento Europeu. Disponível em http://europa.eu/ legislation_summaries/justice_freedom_security/free_movement_of persons_asylum_immigration/ $\overline{13} 3124 \_$en.htm. Accessed on $25^{-}$jul. 2014.

UNIÃO EUROPEIA. Diretiva do Conselho n. 2005/85/EC de $1^{\circ}$ de dezembro de 2005. Conselho Europeu. Disponível em: $\quad$ http://eur-lex.europa.eu/LexUriServ/LexUriServ. do?uri=OJ:L:2005:326:0013:0034:EN:PDF. Accessed on 25 jun. 2014.

VENTURA, Deisy. Qual a Politica Migratória do Brasil? Disponível em http://www.diplomatique.org.br/artigo.php?id=1121 . Accessed on 13.12.2012.

WHITE, Ana Guglielmelli. A pillar of protection: solidarity resettlement for refugees in Latin America. Research UNHCR Paper No. 239. Washington DC, Jun 2012. 26p. 